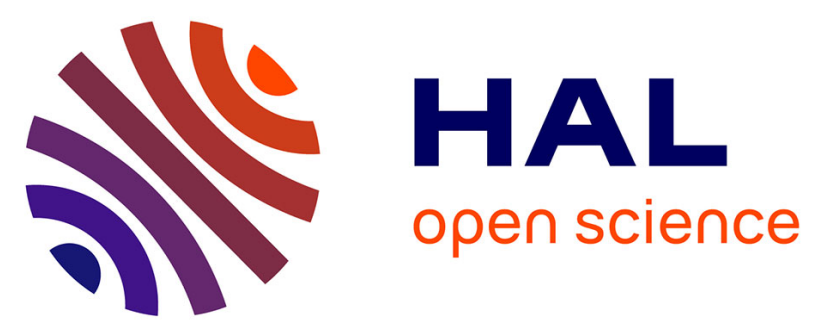

\title{
Characterization of Polymer Waste Containing Nano-fillers Prior its End-of-Life Treatment
}

Dinh Trinh Tran, Aurélie Joubert, Danielle Venditti, Sylvain Durecu, Thierry Meunier, Olivier Le Bihan, Emmanuel Fiani, Laurence Le Coq

\section{- To cite this version:}

Dinh Trinh Tran, Aurélie Joubert, Danielle Venditti, Sylvain Durecu, Thierry Meunier, et al.. Characterization of Polymer Waste Containing Nano-fillers Prior its End-of-Life Treatment. Waste and Biomass Valorization, 2017, 8 (7), pp.2463-2471. 10.1007/s12649-016-9757-0 . hal-01423661

\section{HAL Id: hal-01423661 https://hal.science/hal-01423661}

Submitted on 22 Aug 2019

HAL is a multi-disciplinary open access archive for the deposit and dissemination of scientific research documents, whether they are published or not. The documents may come from teaching and research institutions in France or abroad, or from public or private research centers.
L'archive ouverte pluridisciplinaire HAL, est destinée au dépôt et à la diffusion de documents scientifiques de niveau recherche, publiés ou non, émanant des établissements d'enseignement et de recherche français ou étrangers, des laboratoires publics ou privés. 


\title{
Characterization of Polymer Waste Containing Nano-fillers Prior its End-of-Life Treatment
}

\author{
Dinh Trinh $\operatorname{Tran}^{1,2} \cdot$ Aurélie Joubert $^{1} \cdot$ Danielle Venditti $^{3} \cdot$ Sylvain Durecu $^{3}$. \\ Thierry Meunier ${ }^{4} \cdot$ Olivier Le Bihan $^{2} \cdot$ Emmanuel Fiani $^{5} \cdot$ Laurence Le Coq $^{1}$
}

\begin{abstract}
This study aimed to characterize a polymer waste, originating from polyorganosiloxane polymerization processes, prior its end-of-life treatment in order to identify and quantify the possibly contained nano-fillers. The polymer waste was first characterized in terms of its physical-chemical properties by combining different approaches and analytic techniques such as standard ultimate and elemental analysis or techniques like infrared spectroscopy or thermogravimetric analysis coupled with gas chromatography and mass spectroscopy to define the polymer waste molecular structure. The second step was devoted to identify and characterize the nano-fillers contained in the polymer waste, if any, in terms of particle size distribution, morphology and composition. Due to the thermal degradability of the polymer waste above $50^{\circ} \mathrm{C}$, the cryo-ultramicrotomy and the transmission electron microscopy techniques were used. Polydimethylsiloxane was identified as the core polymer unit, and the presence of the suspected $\mathrm{SiO}_{2}$ nano-fillers was confirmed, with three different morphologies detected: elongated and hexagonal,
\end{abstract}

$凶$ Aurélie Joubert

aurelie.joubert@mines-nantes.fr

1 GEPEA, UMR6144, Mines Nantes, CNRS, 4 rue Alfred Kastler, BP 20722, 44307 Nantes Cedex 03, France

2 INERIS, Parc Technologique Alata, BP 2, 60550 Verneuil-En-Halatte, France

3 R\&D Dept., TREDI - Séché Environnement, 9 avenue de la Forêt de Haye, CS 50184, 54505 Vandœuvre-Lès-Nancy, France

4 Séché Alliance, Les Hêtres, BP 20, 53810 Changé, France

5 Agence de l'Environnement et de la Maîtrise de l'Energie, 20 avenue du Grésillé, BP 90406, 49004 Angers Cedex 01, France both found in the particle size range of $100-500 \mathrm{~nm}$ in diameter; and spherical, present in the population of particles $\leq 100 \mathrm{~nm}$ in diameter. In particular, a relatively large amount of $\mathrm{K}(2.81 \mathrm{wt} \%)$ was also identified in the waste. The mass content of $\mathrm{SiO}_{2}$ nano-fillers in the polymer waste was estimated to $24.4 \mathrm{wt} \%$.

Keywords Waste characterization - Nanowaste . Polydimethylsiloxane $\cdot$ Nano-fillers $\cdot$ Nano-silica End-of-life treatment

\section{Introduction}

In recent years, nanotechnologies have developed in a large variety of industrial sectors, like automobiles, electronics, computers and medicine. To document the marketing and distribution of nanoproducts into the commercial marketplace, the Woodrow Wilson International Center for Scholars and the Project on Emerging Nanotechnologies created the Nanotechnology Consumer Products Inventory (CPI) in 2005 [1]. 1814 consumer products containing nanomaterial were inventoried in 2014 from 622 companies in 32 countries. Silver was the most frequently used nanomaterial (24\%) but $49 \%$ of the products (889) included in the CPI did not provide the composition of the incorporated nanomaterials. Although this inventory does not address comprehensive list of nanoproducts present in the marketplace, it illustrates the worldwide development of nanotechnologies. There has been an impressive global investment in the market for products incorporating nanotechnology, rising from about $\$ 254$ billion in 2009 and expected to reach $\$ 3$ trillion by 2020 [2].

Beside the advantages offered by nanotechnologies, numerous uncertainties also arise regarding their potential 
impact on the environment and human health, due to their exceptional properties and size-dependent functions such as zeta potential, surface charge, surface coating, magnetic and electrical properties and shape [3-5]. For example, the study of nanoparticle toxicity revealed that the nano-size characteristic of a particle may be determinant in its potential toxicity whatever the chemical composition, in other words, nanoparticles may be toxic even if larger particles constituted with the same elements are not [6]. In the perspective of sustainable innovation, the development of nanotechnologies requires a deep insight into nanosafety during the whole life cycle of products containing nanomaterials, from production to recycling and final destruction. For example, the European GUIDEnano research project, started in 2013, is developing a web-based guidance tool, which will help the nanoproduct users to design and apply of the most appropriate risk assessment and mitigation strategy for a specific product. In complement to the existing regulations in different frameworks, the tool will be used by industry to evaluate and efficiently mitigate possible health risks for workers, consumers and the environment associated to the use of nanotechnologies. In particular, the GUIDEnano project should propose suitable strategies to handle nano-enabled products at all the stages of their life cycle in order to minimize the potential for occupational or environmental exposure.

To date, there is no specific approved procedure for the waste management of nanoproducts and nanomaterials at their end of life, which can be called nanowaste. The organization for economic co-operation and development (OECD) published in 2016 current knowledge (non-exhaustive state-of-the-art) on the fate and possible impacts of nanomaterials in specific waste treatment processes, including recycling, incineration, landfilling and wastewater treatment processes [7]. Whatever the waste treatment process, the characterization of the nanomaterials, in terms of chemical composition and other characteristics including shape, size and structure, is required to understand the fate and behavior of nanomaterials in the process or their potential pathways of release to the environment. The lack of standard method makes it difficult for the nanomaterial or nanoproduct characterization for waste management industry. One further research recommended by the OECD [7], based on the importance of the topic and the absence of sufficient knowledge in the literature, is the identification and quantification of the nanomaterials entering waste treatment processes.

This study aims to characterize the physical-chemical properties of a polymer waste of unknown composition and in particular to identify, describe and quantify the nanofillers integrated into the polymer. Such characterization of polymer waste suspected to be a nanowaste may guide decision making about waste management.

\section{Materials and Methods}

\section{Selected Polymer Waste}

An industrial polymer waste in bulk-solid form was selected, sampled and provided by TREDI-Séché Environnement, a French specialist of hazardous waste treatment, as likely to contain nano-fillers. The polymer waste was originated from polyorganosiloxane polymerization processes. The selection of the polymer waste for the study was motivated by the large production of silicon dioxide $\left(\mathrm{SiO}_{2}\right)$ nanomaterials in the world, with average quantities of 5500 tons/year [8], widely extended to several industrial fields like chemical separation, car tires, printing inks, pharmaceuticals, cosmetics, and even animal feed [8].

\section{Physical and Chemical Analysis of the Polymer Waste}

\section{Proximate Analysis}

The polymer waste was analyzed to determine the moisture and the volatile organic compound (VOC) contents. The moisture of a waste sample is generally determined according to standard method, e.g. in NF EN 14346:2007 at $105 \pm 3{ }^{\circ} \mathrm{C}$ until constant mass in a ventilated oven. Nevertheless, preliminary thermogravimetric analysis showed a degradation of polymer waste samples above $50{ }^{\circ} \mathrm{C}$. Therefore, to quantify the exact proportion of water in the polymer waste, the Karl Fischer titration method was used, as recommended in the standard NF EN 14346:2007 when volatile compounds are encountered. Experiments were performed at $50{ }^{\circ} \mathrm{C}$ using a Karl Fischer apparatus (870KF-Titrino-plus and 860KF-Thermoprep) with $120 \mathrm{mg}$ of polymer waste samples to determine the moisture and VOC contents.

The ash content was determined by heating $1 \mathrm{~g}$ of dried polymer waste sample in an oven at $815 \pm 10^{\circ} \mathrm{C}$ until constant mass, according to ISO 1171:2010. As for all other physical-chemical parameters, the tests were conducted in three replicates and the samples were previously dried at $50{ }^{\circ} \mathrm{C}$ until constant mass.

\section{Loss on Ignition}

The loss on ignition is the change in mass resulting from the heating of a sample under specified conditions. The amount of organic compounds (polycyclic aromatic hydrocarbons, organochlorine pesticides and poly chlorinated biphenyls) in the polymer waste was determined according to NF EN 15169:2007. A $1 \mathrm{~g}$ aliquot of the dried sample was heated in a ventilated oven at $550 \pm 25^{\circ} \mathrm{C}$ 
under atmospheric conditions for $5 \mathrm{~h}$. The organic content is approximately equal to the weight loss due to volatilization of the dry sample at $550{ }^{\circ} \mathrm{C}$ : organic matter is efficiently removed by combustion at $550{ }^{\circ} \mathrm{C}$, whereas only carbonate minerals begin to decompose thermally at such a temperature.

\section{Gross Calorific Value}

The calorific value is an important parameter for end-oflife thermal treatment because it permits to estimate the ability of a waste to burn without adding supporting fuel. The gross calorific value, i.e. the total amount of heat released when the waste is burned, was measured by calorimetric bomb method (Calorimeter-Parr-6200) with certified benzoic acid as a reference to measure the thermal capacity of the bomb calorimeter, according to ISO 1928:2009. The dried polymer waste samples of $500 \mathrm{mg}$ were pelletized for ignition in the assembled combustion bomb.

\section{Ultimate Analysis (Percent of CHNS)}

The percents of carbon, hydrogen, nitrogen and sulphur in the polymer waste were quantified with a Thermo-Scientific-FlashEA ${ }^{\circledR} 1112$ elemental analyzer, operating by dynamic flash combustion of the sample at $950^{\circ} \mathrm{C} .1 \mathrm{mg}$ of dried polymer waste samples were analyzed (with $1 \mu \mathrm{g}$ readability) in tin containers.

\section{Elemental Analysis}

Polymer waste samples were subjected to inductivelycoupled plasma (ICP) to estimate their elementary chemical composition. Two physical analysis techniques by spectrometry were performed: the ions created by ICP were separated by mass spectrometry according to their charge and mass with a signal proportional to the number of ions (ICP-MS), and the photons created by ICP were counted by atomic emission (ICP-AES).

Such techniques require mineralization by dissolution (acidification and oxidation) of the waste samples. Dried polymer waste samples of $10 \mathrm{mg}$ were dissolved according to NF EN 13657:2003: samples dissolved. in aqua regia $\left(\mathrm{HNO}_{3} / \mathrm{HCl}=1 / 3, \mathrm{v} / \mathrm{v}\right)$ were heated at $200^{\circ} \mathrm{C}$ in Teflon reactors, in a microwave oven (Ethos TC, Milestone). To enhance the solubilization of $\mathrm{Si}$ contained in silica, the alkali-fusion decomposition method with $\mathrm{LiBO}_{2}-\mathrm{Li}_{2} \mathrm{~B}_{4} \mathrm{O}_{7}$ was also applied to the samples, because of the well-known recalcitrance of such mineral phases to digestion with hot aqua regia.

Finally, 12 elements (Al, $\mathrm{Ca}, \mathrm{Cr}, \mathrm{Cu}, \mathrm{Fe}, \mathrm{K}, \mathrm{Mg}, \mathrm{Na}, \mathrm{Sb}$, $\mathrm{Si}, \mathrm{Ti}, \mathrm{Zn})$ were quantified in the polymer waste samples.

\section{Molecular Structure}

In addition to ultimate and elemental analysis, Fourier transform infrared spectroscopy (FTIR) measurements were performed to identify the chemical compounds and functional groups in the polymer waste. The measurements were performed with a Thermo-Nicolet-Nexus-670 using a $\mathrm{SiC}$ source, and TDGS detector. IR spectra were scanned between 4000 and $400 \mathrm{~cm}^{-1}$, with a resolution of $4 \mathrm{~cm}^{-1}$, and saved by attenuated total reflection in monoreflection on a crystal of germanium or diamond. The dried samples were previously ground to obtain fine powders. The measurements were carried out with the $\mathrm{KBr}$ disk method.

To complete the analysis of the molecular structure of the polymer waste, the compounds formed by the thermal decomposition of samples were analyzed by thermogravimetric analysis combined with gas chromatography and mass spectrometry (TGA-GC/MS). The thermal decomposition of dried polymer waste samples of $1-1.5 \mathrm{mg}$ was performed by a TGA/AT instrument-Q50. An air flow rate of $45 \mathrm{~mL} / \mathrm{min}$ was applied to purge the sample area in a quartz furnace, and a helium flow rate of $5 \mathrm{~mL} / \mathrm{min}$ was set as the purge gas for the microbalance. Two cycles of heating were applied: from 19 to $105^{\circ} \mathrm{C}\left(5^{\circ} \mathrm{C} / \mathrm{min}\right)$ and from 105 to $850{ }^{\circ} \mathrm{C}\left(5^{\circ} \mathrm{C} / \mathrm{min}\right)$. For the two cycles, the compounds formed in the gas phase were fixed in an absorbent cartridge (Tenax or Chromosorb106) for later analysis with a Markes-Unity thermal desorber coupled with a GC-MS (Agilent-6890/5973 N). The column was a DB-VRX, $30 \mathrm{~m}$ in length, $0.25 \mathrm{~mm}$ in diameter, and $1.4 \mu \mathrm{m}$ in thickness.

\section{Characterization of the Nano-fillers in the Polymer Waste}

The size and morphology of nano-fillers incorporated into the polymer were characterized by transmission electron microscopy (TEM), and the elemental composition of the nano-fillers was determined using energy dispersive X-ray spectrometers (EDX) integrated into the TEM system. This analytical technique was combined with preliminary preparation of the polymer waste samples by slicing them into small sections by ultramicrotomy. The Leica ultramicrotome (EM-UC7) with glass blades was used to slice samples into sections of $100 \mathrm{~nm}$ in thickness. Due to the degradability of the polymer waste at moderate temperature, the samples were frozen at $-160^{\circ} \mathrm{C}$ in liquid nitrogen and the freezing temperature was maintained during cryo-sectioning. The slices were collected on TEM copper grids coated with holey carbon film. They were observed by a TEM (Hitachi-HF-2000) at $-180^{\circ} \mathrm{C}$ with liquid nitrogen. 


\section{Results and Discussion}

\section{Physical-Chemical Characterization of Nanowaste}

\section{Combustible Quality}

The combustible quality of the polymer waste was determined to address the incineration as end-of-life waste management option. When the waste was heated in the presence of air, the primary loss of material (92.7 $\pm 1.5 \mathrm{wt} \%$, average value \pm standard deviation with $\mathrm{N}=3$ ) was observed below $525^{\circ} \mathrm{C}$, including the loss of VOCs $(4.9 \pm 0.6 \mathrm{wt} \%)$ and $\mathrm{H}_{2} \mathrm{O}(25.0 \pm 0.8 \mathrm{wt} \%)$ at $50{ }^{\circ} \mathrm{C}$, and the loss of the main organic fraction $(62.8 \pm 0.1 \mathrm{wt} \%)$ from 50 to $525^{\circ} \mathrm{C}$. A small amount of material $(1.0 \pm 0.6 \mathrm{wt} \%)$ was lost between 525 and $815^{\circ} \mathrm{C}$ (including the residual organic fraction, the structural water and the carbonates), and the ash content (residual inorganic fraction) was $5.9 \pm 0.8 \mathrm{wt} \%$ at $815^{\circ} \mathrm{C}$.

Such determinations of loss on ignition values were completed by thermogravimetric analysis (Fig. 1). The results showed three degradation steps of the polymer waste in presence of air. The first degradation leads to a weight loss of $10 \%$ at $90{ }^{\circ} \mathrm{C}\left(45-130{ }^{\circ} \mathrm{C}\right.$ for the beginning and the end of the peak); it is probably associated with the evaporation of VOCs and the initial degradation of the polymer chain. Note that the $10 \%$ weight loss is coherent with the $4.9 \%$ of VOCs loss at $50{ }^{\circ} \mathrm{C}$ from Karl Fisher experiments. The second degradation is maximal at $178{ }^{\circ} \mathrm{C}$ with a weight loss of $50 \%$ and partially overlaps the third step, whose significant mass change $(20 \%)$ is maximal at $225^{\circ} \mathrm{C}$. The residual mass of the sample after the third degradation peak $\left(300{ }^{\circ} \mathrm{C}\right)$ remained almost unchanged at around $10 \%$ until $850{ }^{\circ} \mathrm{C}$ at around $10 \%$, meaning $90 \%$ of overall weight loss. This result is coherent with the loss on ignition values, i.e. around $93 \%$ of total weight loss after $5 \mathrm{~h}$ at $525^{\circ} \mathrm{C}$. After the $10 \mathrm{~min}$ of thermogravimetric analysis, the ash content at $850{ }^{\circ} \mathrm{C}$ represented $9.8 \%$ of the initial mass, which is coherent with the value of $5.9 \mathrm{wt} \%$ obtained for a much longer period $(5 \mathrm{~h})$ at $815^{\circ} \mathrm{C}$.

The calorimetric analysis showed a large amount of heat per unit weight of waste produced by complete combustion, with a gross calorific value up to $27.63 \mathrm{~kJ} / \mathrm{g}(6.6 \mathrm{kcal} /$ g). The value suggests a fairly good heating ability for the polymer waste compared to a typical combustible like coal, whose heat of combustion is commonly in the range $6.3-8.7 \mathrm{kcal} / \mathrm{g}$ [9].

\section{Elemental Chemical Composition}

The results of the ultimate and elemental analysis are presented in Table 1. The polymer waste contains two
Table 1 Major, minor and trace contents (mg/kg dw)

\begin{tabular}{|c|c|c|c|c|c|}
\hline \multicolumn{6}{|c|}{ Organic elements $(\mathrm{N}=3)$, average value \pm standard deviation } \\
\hline \multicolumn{2}{|l|}{$\mathrm{C}$} & \multicolumn{2}{|l|}{$\mathrm{H}$} & $\mathrm{N}$ & S \\
\hline \multicolumn{2}{|c|}{$207,800 \pm 1400$} & $54,600 \pm$ & & $<500$ & $<500$ \\
\hline \multicolumn{6}{|c|}{ Inorganic and metalloid elements $(\mathrm{N}=2)$, average value } \\
\hline $\mathrm{Si}^{\mathrm{b}}$ & $\mathrm{K}^{\mathrm{a}}$ & $\mathrm{Na}^{\mathrm{a}}$ & $\mathrm{Fe}^{\mathrm{a}}$ & $\mathrm{Al}^{\mathrm{a}}$ & $\mathrm{Ca}^{\mathrm{a}}$ \\
\hline 39,100 & 28,100 & 523 & 228 & $<5$ & 38 \\
\hline $\mathrm{Cu}^{\mathrm{a}}$ & $\mathrm{Sb}^{\mathrm{a}}$ & $\mathrm{Zn}^{\mathrm{a}}$ & $\mathrm{Cr}^{\mathrm{a}}$ & $\mathrm{Mg}^{\mathrm{a}}$ & $\mathrm{Ti}$ \\
\hline$<5$ & $<20$ & 7.4 & $<5$ & 10 & $<5$ \\
\hline
\end{tabular}

Sample digestion by ${ }^{a}$ aqua regia ${ }^{b}$ alkali-fusion

main elements, $\mathrm{C}$ and $\mathrm{H}$, whereas the presence of $\mathrm{N}$ and $\mathrm{S}$ is negligible. The average proportions of $\mathrm{C}$ and $\mathrm{H}$, expressed in total dry weight percent (dwt\%), are 20.78 and $5.46 \mathrm{dwt} \%$, respectively, with relatively small standard deviations ( $<10 \%$ of average values); mean recovery rates for $\mathrm{C}, \mathrm{H}, \mathrm{N}$, and $\mathrm{S}$ in reference materials are very high with 97, 98, 98, 97\%, respectively. The polymer waste contains significant proportions of $\mathrm{Si}$ and $\mathrm{K}$, which account for 3.91 and $2.81 \mathrm{dwt} \%$, respectively. The presence of other elements is either below trace levels ( $\mathrm{Al}, \mathrm{Ca}, \mathrm{Cr}, \mathrm{Cu}, \mathrm{Mg}, \mathrm{Sb}$, $\mathrm{Ti}, \mathrm{Zn}$ ), or in small quantities $<0.10 \mathrm{dwt} \%$ (Fe, Na). The average recovery rates of reference materials of these metals solubilized by aqua regia are higher than $90 \%$, except for $\mathrm{Si}$, which presents a recovery rate of less than $50 \%$.

The degree of rigidity of the macromolecule network increases with the amount of silica incorporated and dispersed in the elastomer. The fire retardant properties of silicone elastomers are known to be intrinsically linked to the release of silica residues when exposed to elevated temperature. The released silica serves as an "insulating blanket", which acts as a mass transport barrier delaying the volatilization of decomposition products. Therefore, it reduces the amount of volatiles compounds available for burning in the gas phase and the heat that feeds back to the polymer surface [10].

\section{Identification of Molecular Structure}

The FTIR spectrum for the polymer waste is shown in Fig. 2. Three characteristic bands at 798.9, 1018.8 and $1088.8 \mathrm{~cm}^{-1}$ are assigned to $\mathrm{Si}-\mathrm{O}-\mathrm{Si}$ vibrations [11-14]. The first one corresponds to the symmetric Si-O-Si stretch, while the others are affected by the asymmetric $\mathrm{Si}-\mathrm{O}-\mathrm{Si}$ stretch $[12,15]$. Note that the $\mathrm{Si}-\mathrm{O}-\mathrm{Si}$ bonds may be 
(a)

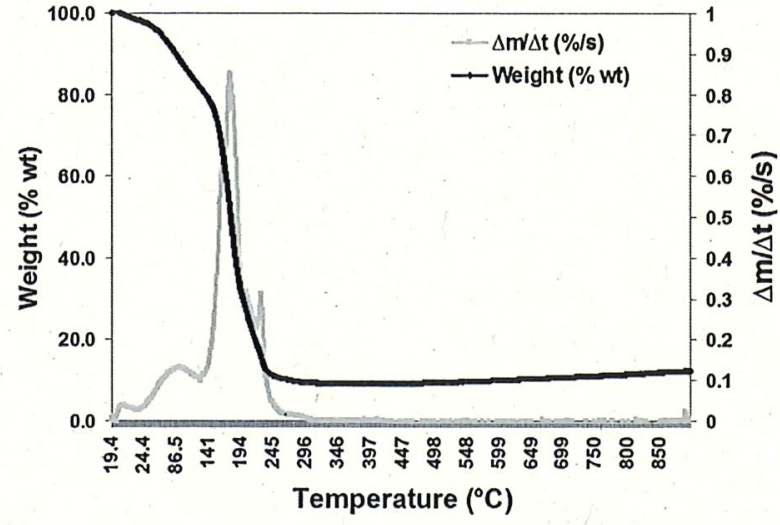

(b)

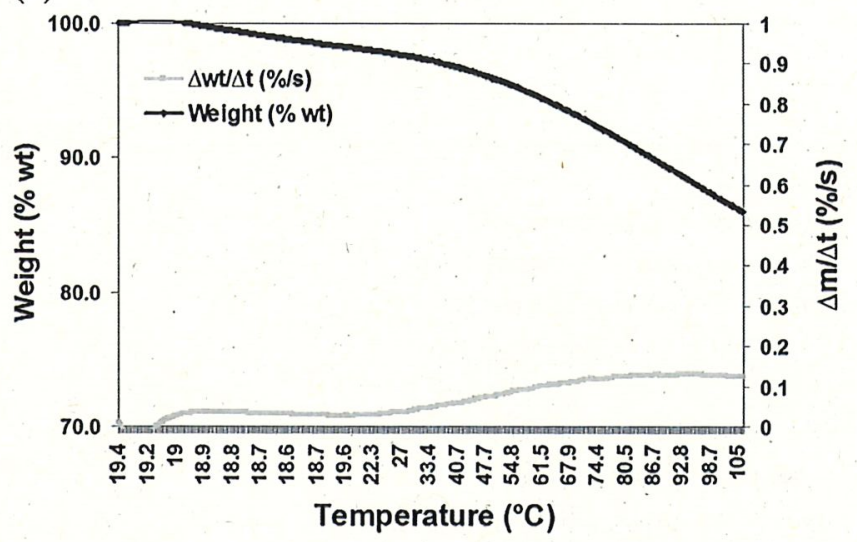

Fig. 1 TGA-analysis from 19 to $850{ }^{\circ} \mathrm{C}$ (a) and zoom on the $19-105^{\circ} \mathrm{C}$ range (b)

present either in the polymer structure or in the nano-fillers (nano- $\mathrm{SiO}_{2}$ ).

The band at $798.9 \mathrm{~cm}^{-1}$ is associated with vibrations of $\mathrm{Si}-\mathrm{CH}_{3}$ stretching and $\mathrm{CH}_{3}-$ rocking [13]. The relatively weak absorption peak at $863.4 \mathrm{~cm}^{-1}$ belongs to blocks of dimethyl D units [16]. The absorption peaks at 2963 and $2905.5 \mathrm{~cm}^{-1}$ are affected by stretching vibrations of $\mathrm{CH}$ and $\mathrm{CH}_{3}$ in the side-chain of the polymer [11], while the band at $1260.3 \mathrm{~cm}^{-1}$ is assigned to $\mathrm{CH}_{3}$ symmetric deformation of $\mathrm{Si}-\mathrm{CH}_{3}$ [13]. The infrared band at $1398.6 \mathrm{~cm}^{-1}$ can be linked to symmetric $\mathrm{CH}_{3}$ bending vibrations. Additional characteristic bands observed at 3346.4 and $1647.4 \mathrm{~cm}^{-1}$ are affected by vibrations of $\mathrm{OH}$ stretching and $\mathrm{OH}$ bending of hydroxyl groups, respectively, adsorbed on the surface of either the polymer or the $\mathrm{SiO}_{2}$ nano-fillers $[15,17]$.

These results from FTIR analysis indicate that the polymer waste contains principally polydimethylsiloxane (PDMS) $\left[-\mathrm{Si}\left(\mathrm{CH}_{3}\right)_{2}-\mathrm{O}\right]_{\mathrm{n}}, \mathrm{SiO}_{2}$ present either in the polymer structure or in the nano-fillers, and water absorbed on the polymer and/or $\mathrm{SiO}_{2}$ surfaces.
Formation of Silicon Compounds from the Combustion of Polymer Waste Containing Nano-fillers

The identification by GC/MS of the compounds formed by thermogravimetric analysis of the polymer waste permitted to complete the determination of its molecular structure. The thermal oxidative degradation of the polymer waste were described from 25 to $105{ }^{\circ} \mathrm{C}$, and from 105 to $850{ }^{\circ} \mathrm{C}$ in oxidative conditions (air). The main products formed in both steps are shown in Table 2. The principal fragments formed during the two thermal steps are cyclic oligomers, hexamethylcyclotrisiloxane being the smallest cyclic product, confirming the previous FTIR results suggesting that the polymer waste is PDMS-based. A number of smaller compounds present in minor or trace contents $(<3 \%)$ were also detected, but not identified in the spectrum libraries of common molecules. The products formed during the second step (at higher temperature) of the oxidative degradation of the polymer waste contain unidentified and smaller compounds than during the first step. In addition, the comparison of relative surface densities of the products

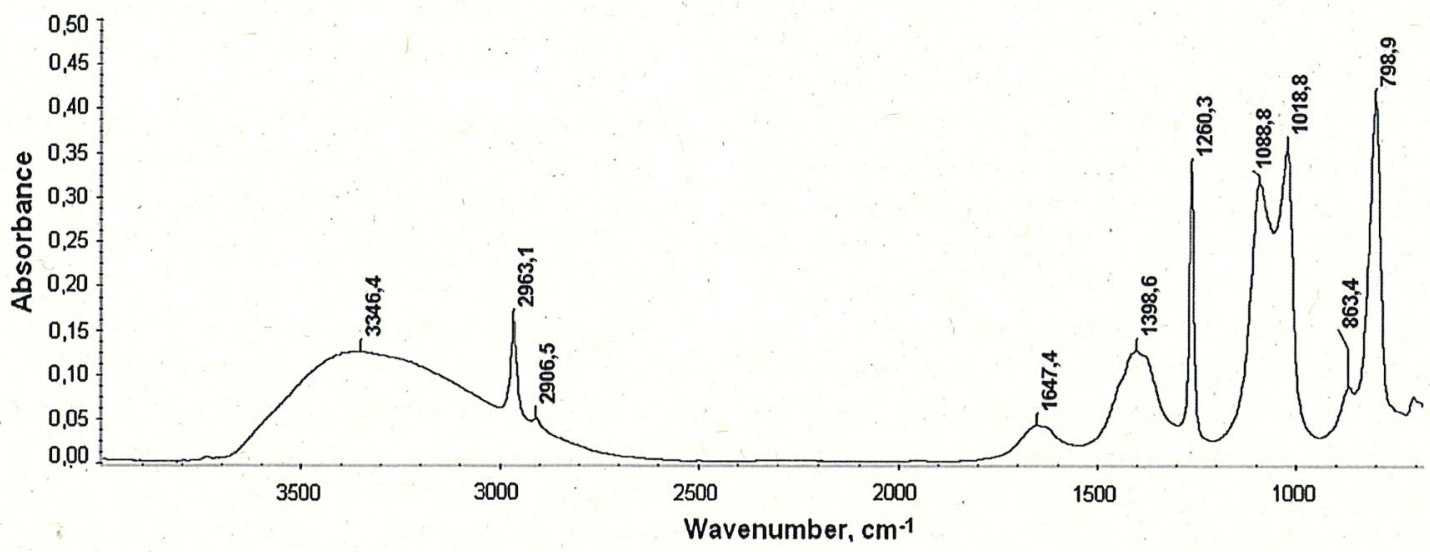

Fig. 2 FTIR spectrum in ambient conditions 
Table 2 Thermal oxidative degradation products from GC-MS

\begin{tabular}{lcc}
\hline & Retention time (s) & $\begin{array}{c}\text { Surface intensity } \\
\text { (relative value compared } \\
\text { to tetramer, \%) }\end{array}$ \\
\hline $25-105{ }^{\circ} \mathrm{C}$ & & 100.00 \\
Cyclotetrasiloxane, octamethyl & 17.09 & 83.82 \\
Cyclopentasiloxane, decamethyl & 21.986 & 52.78 \\
Cyclohexasiloxane, dodecamethyl & 26.402 & 17.07 \\
Cycloheptasiloxane, tetradecamethyl & 30.197 & 100.00 \\
$105-850{ }^{\circ} \mathrm{C}$ & & 87.26 \\
Cyclotetrasiloxane, octamethyl & 17.056 & 57.12 \\
Cyclotrisiloxane, hexamethyl & 6.697 & 52.83 \\
Cycloheptasiloxane, tetradecamethyl & 30.278 & 46.08 \\
Cyclohexasiloxane, dodecamethyl & 26.564 & 27.62 \\
Cyclopentasiloxane, decamethyl & 21.997 & 14.83 \\
Silane, [[4-[1,2-bis[(trimethylsilyl)oxy]ethyl]-1,2-phenylene]bis(oxy)]bis[trimethyl] & 33.752 & 6.49 \\
Cyclononasiloxane, octadecamethyl & 36.73 & 39.378 \\
Cyclodecasiloxane, eicosamethyl & & \\
\hline
\end{tabular}

formed during both steps reveals that about $35 \%$ of cyclic oligomers were formed in the first step through depolymerization in the temperature range of $50-105^{\circ} \mathrm{C}$. This may be attributed to the presence of water and impurities such as $\mathrm{Na}, \mathrm{Fe}, \mathrm{Ca}, \mathrm{Al}$, and particularly $\mathrm{K}$ which was found in significant proportion in the polymer waste $(2.81 \mathrm{dwt} \%)$ from elemental analysis. The significant amount of $\mathrm{K}$ in the sample could be attributed to the use of $\mathrm{KOH}$ as a catalyst for ring-opening polymerization or polycondensation [10]. The presence of these elements and water may thus result in an accelerated decomposition of polymer, leading to a decrease in the temperature of depolymerization by an externally catalyzed mechanism [10].

Regarding the first step, tetramers and pentamers are the most abundant among the cyclic oligomers formed, with a ratio of pentamers/tetramers equivalent to $83.8 \%$. This observation is quite different from studies in the literature [18] which report that, according to a normal distribution rule, trimers and tetramers should be the most abundant. However, most previous studies were performed at high temperature, up to $400{ }^{\circ} \mathrm{C}$ and higher $[10,18,19]$, whereas during the present study, the polymer waste sample was only heated up to $105^{\circ} \mathrm{C}$ in the first step, probably explaining the absence of trimers as major products. In this low temperature range, on the one hand, the supplied energy is not high enough to break down higher oligomers into smaller ones (trimers) with improved thermodynamic stability and, on the other hand, the condensation of fragments forming higher oligomers may become significant. Regarding the second step, as expected, the trimers and tetramers are the most abundant products with a tetramer/

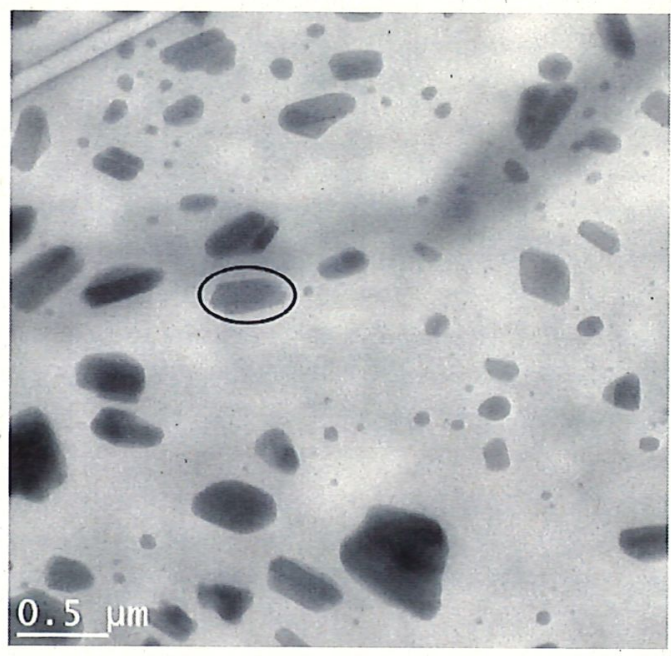

Fig. 3 Morphology of nano-fillers by TEM (4.9 k magnification)

trimer ratio equivalent to $87.3 \%$, while higher cyclic oligomers, such as pentamers, hexamers, and heptamers, present comparable amounts close to $30 \%$. Moreover, during this step, more compounds were observed in the gas phase including unidentified ones. These results are in accordance with Camino et al. [18], in which PDMS was heated in air to $800{ }^{\circ} \mathrm{C}$ at a heating rate of $80^{\circ} \mathrm{C} / \mathrm{min}$. Finally, it should be notice that the heating rate, the nature of PDMS (functional, end-groups), the fillers, additives, and impurities may result in different combustion mechanisms of this polymer, hence forming different kinds of compounds $[10,18,19]$. 


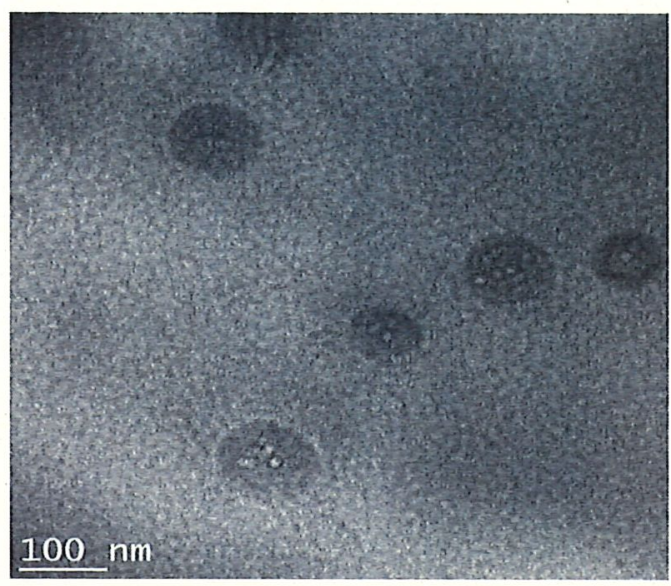

Fig. 4 Morphology of the smallest population of nano-fillers (spherical shape) by TEM ( $25 \mathrm{k}$ magnification)

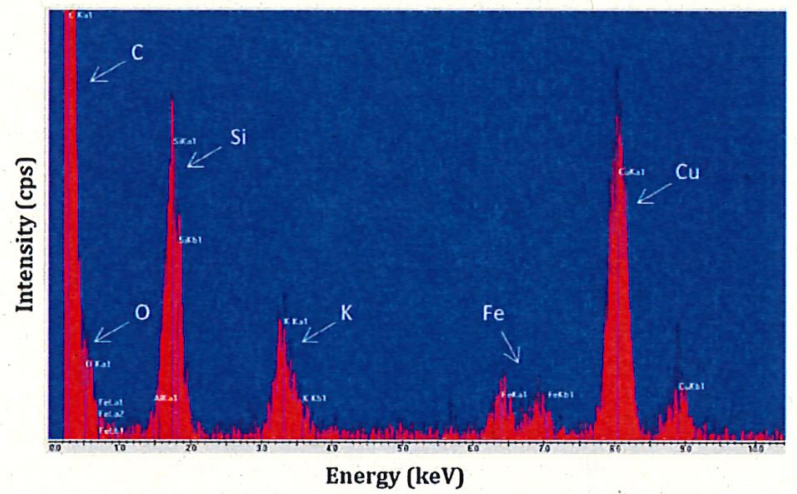

Fig. 5 EDX analysis of elongated and hexagonal particles

\section{Nano-fillers Identification}

Polymer waste samples were first observed by TEM to identify the possibly contained nano-fillers, revealing that the fillers in the polymer matrix contain only submicron particles (Fig. 3): three morphological shapes can be identified (1) elongated and (2) hexagonal, both found in the particle size range of $100-500 \mathrm{~nm}$ in diameter with elongated particles being somewhat smaller than hexagonal ones; and (3) spherical, present in the population of particles $\leq 100 \mathrm{~nm}$ in diameter (Fig. 4). These particle populations are well dispersed in the polymer matrix, and no significant aggregation is observed.

Regarding the chemical composition of particles, the results obtained by EDX indicated similar compositions in both hexagonal and elongated populations. Example of EDX spectrum of analyzed particles is presented Fig. 5 (spectrum corresponding to the particle encircled in Fig. 3). They contain mainly two elements, Si and $\mathrm{K}$, in decreasing orders of magnitude, and a small amount of $\mathrm{Fe}$, suggesting either Fe impurity or the use of additives such as $\mathrm{FeO}, \mathrm{Fe}_{2} \mathrm{O}_{3}$, or mica $\mathrm{KAl}_{2}\left(\mathrm{Si}_{3} \mathrm{Al}\right) \mathrm{O}_{10}(\mathrm{OH})_{2}[10]$ in the polymer waste. The latter assumption, however, can be excluded because, according to the elemental and EDX analysis, the proportion of $\mathrm{Al}$ is significantly lower than that of Fe, K, and Si. For particles smaller than $100 \mathrm{~nm}$, they are primarily constituted of $\mathrm{Si}, \mathrm{O}$, and a small amount of $\mathrm{Fe}$, suggesting the presence of nano- $\mathrm{SiO}_{2}$. In comparison with Cendrowski et al. [20], who studied the upstream product (synthesized nanomaterial), the present polymer waste (downstream product) should contain nanospherical $\mathrm{SiO}_{2}$. The presence of $\mathrm{Fe}$ can be associated with nanofillers containing both $\mathrm{Fe}$ and $\mathrm{Si}$, such as nano- $\mathrm{Fe}_{3} \mathrm{O}_{4}$ coated with $\mathrm{SiO}_{2}$ reported in Ahangaran et al. [15]. However, our FTIR analysis of the polymer waste did not allow to identify typical $\mathrm{Si}-\mathrm{O}-\mathrm{Fe}$ vibration band at $578 \mathrm{~cm}^{-1}$ and, according to the elemental analysis (Table 1) the $\mathrm{Fe}$ content is negligible compared to the $\mathrm{Si}$ one. Fe is therefore rather attributed to impurities, and its presence in the EDX spectra can be assigned to $\mathrm{Fe}$ in the matrix located close to the nano-fillers.

\section{Estimation of Percentage of $\mathrm{SiO}_{2}$ Nano-fillers}

Silica is the most common filler incorporated into PDMS because of its reinforcing effect induced by hydrogen bonds between the oxygen atoms of $\mathrm{Si}-\mathrm{O}$ in the PDMS chain and the hydrogen atoms of silanol groups on the surface of silica [10]. The percentage of $\mathrm{SiO}_{2}$ nano-fillers integrated into the polymer (PDMS-based) waste was estimated from mass balance.

In the first step, the quantity of $\mathrm{Si}$ and $\mathrm{O}$ elements present in polymer chains was calculated from the PDMS formula $\left[-\mathrm{Si}\left(\mathrm{CH}_{3}\right)_{2}-\mathrm{O}\right]_{\mathrm{n}}$ based on the $\mathrm{C}$ content revealed by the ultimate analysis (CHNS). Neglecting the endgroups of PDMS in the sample, the $\mathrm{Si} / \mathrm{C}$ mass ratio is $28 / 24$, and the $\mathrm{C} / \mathrm{O}$ mass ratio is $24 / 16$. Considering a measured average percentage of elemental carbon of $20.8 \mathrm{dwt} \%$, Si and $\mathrm{O}$ contents in PDMS are 24.3 and $13.9 \mathrm{dwt} \%$, respectively, assuming that $\mathrm{C}$ is mainly present in PDMS. Interestingly, Schnyder et al. [21] reported atomic concentrations of $\mathrm{C}, \mathrm{Si}$, and $\mathrm{O}$ measured in common PDMS close to theoretical values.

The nano- $\mathrm{SiO}_{2}$ fillers were therefore calculated by subtracting C (20.8 dwt\%), Si in PDMS (24.3 dwt\%), O in PDMS (13.9 dwt\%), $\mathrm{H}$ contents in the polymer (5.5 dwt\%) and total major and minor element contents in the polymer apart from $\mathrm{Si}(3.0 \mathrm{dwt} \%$ for $\mathrm{N}, \mathrm{S}, \mathrm{K}, \mathrm{Na}, \mathrm{Fe}, \mathrm{Al}, \mathrm{Ca}, \mathrm{Cu}$, $\mathrm{Sb}, \mathrm{Zn}, \mathrm{Cr}, \mathrm{Mg}$, Ti) from the initial dry mass of the sample. In this way, the nano- $\mathrm{SiO}_{2}$ percentage was estimated to $32.5 \mathrm{dwt} \%$ or $24.4 \mathrm{wt} \%$ (considering $25 \%$ of water 
content). This concentration of nano- $\mathrm{SiO}_{2}$ is commonly introduced into PDMS as a filler to improve its mechanical properties and enhance its optical clarity [10].

It should be noted that, according to this calculation, the total proportion of $\mathrm{Si}$ in the polymer waste will be $39.5 \mathrm{dwt} \%$ (24.3 dwt\% in the PDMS and $15.2 \mathrm{dwt} \%$ in nano- $\mathrm{SiO}_{2}$ ), whereas this value is $3.9 \mathrm{dwt} \%$ according to the analysis of total Si content performed by ICP-MS using alkali-fusion technique (Table 1). This technique is normally used as the standard method for Si recovery from silicate minerals [22]. The difference between the calculated and measured Si contents can be attributed to the fact that the PDMS contains a large amount of $\mathrm{Si}$ in its chains and, in our study, an open crucible was used for the sample digestion, which may result in the loss of volatile $\mathrm{Si}$ compounds, for example through the formation of cyclic oligomers (trimers, tetramers, pentamers). The concentration of Si obtained by ICP-MS measurement is probably strongly associated with the $\mathrm{SiO}_{2}$ nano-fillers.

\section{Conclusions}

The polymer waste, originating from polymerization processes of polysiloxane, was shown to be primarily constituted of polydimethylsiloxane, $\mathrm{SiO}_{2}$ nano-fillers, and $\mathrm{K}$, probably used as a catalyst $(\mathrm{KOH})$ for ring-opening polymerization and/or polycondensation. The polymer waste was also shown to be thermally degradable from low temperature of around $50{ }^{\circ} \mathrm{C}$. The presence of nano-fillers was confirmed with three morphological shapes identified in the polymer waste samples studied: (1) elongated and (2) hexagonal, both found in the particle size range of $100-500 \mathrm{~nm}$, and (3) spherical, present in the population of particles of diameter less than $100 \mathrm{~nm}$. The percentage of $\mathrm{SiO}_{2}$ nano-fillers probably incorporated in the polymer to reinforce its mechanical and optical properties, was estimated to $24.4 \mathrm{wt} \%$. The combination of different techniques used in this study could be applied to characterize other nanowaste in solid form.

Acknowledgements This project, entitled NanoFlueGas, was financially supported by the French Agency for Environment and Energy Management (ADEME) through its CORTEA funding scheme (Grant No. 1181C0088). The authors would like to thank the IMN Laboratory for microscopic analysis.

\section{References}

1. Vance, M.E., Kuiken, T., Vejerano, E.P., McGinnis, S.P., Hochella Jr., M.F., Rejeski, D., Hull, M.S.: Nanotechnology in the real world: redeveloping the nanomaterial consumer products inventory. Beilstein J. Nanotechnol. 6, 1769-1780 (2015)
2. Roco, M.C., Mirkin, C.A., Hersam, M.C.: Nanotechnology research directions for societal needs in 2020: summary of international study. J. Nanopart. Res. 13, 897-919 (2011)

3. Borm, P.J.-A., Robbins, D., Haubold, S., Kuhlbusch, T., Fissan, H., Donaldson, K., Schins, R., Stone, V., Kreyling, W., Lademann, J., Krutmann, J., Warheit, D., Oberdorster, E.: The potential risks of nanomaterials: a review carried out for ECETOC. Part: Fibre Toxicol. 3, 11 (2006)

4. Som, C., Wick, P., Krug, H., Nowack, B.: Environmental and health effects of nanomaterials in nanotextiles and façade coatings. Environ. Int. 37, 1131-1142 (2011)

5. Bondarenko, O., Juganson, K., Ivask, A., Kasemets, K., Mortimer, M., Kahru, A.: Toxicity of $\mathrm{Ag}, \mathrm{CuO}$ and $\mathrm{ZnO}$ nanoparticles to selected environmentally relevant test organisms and mammalian cells in vitro: a critical review. Arch. Toxicol. 87, 1181-1200 (2013)

6. Fratoddi, I., Venditti, I., Cametti, C., Russo, M.V.: How toxic are gold nanoparticles? the state-of-the-art. Nano Res. doi:10.1007/ s12274-014-0697-3 (2014)

7. OECD: Nanomaterials in Waste Streams: Current Knowledge on Risks and Impacts, OECD Publishing, Paris. doi:10.1787/ 9789264249752-en (2016)

8. Piccinno, F., Gottschalk, F., Seeger, S., Nowack, B.: Industrial production quantities and uses of ten engineered nanomaterials in Europe and the world. J. Nanopart. Res. 14(9), 1-11 (2012)

9. Griepink, B., Wilkinson, H.C., Scholz, A.: The certification of the ash content and of the gross calorific value of three coals. Report, EUR 11000 (1987)

10. Hamdani, S., Longuet, C., Perrin, D., Lopez-Cuesta, J.M., Ganachaud, F.: Flame retardancy of silicone-based materials. Polym. Degrad. Stab. 94, 465-495 (2009)

11. Huang, W., Yibei, F., Chaoyang, W., Yunshu, X., Zhishang, B.: A study on radiation resistance of siloxane foam containing phenyl. Radiat. Phys. Chem. 64, 229-233 (2002)

12. Kim, D.S., Park, H.B., Rhim, J.W., Lee, Y.M.: Preparation and characterization of crosslinked PVA/SiO2 hybrid membranes containing sulfonic acid groups for direct methanol fuel cell applications. J. Membr. Sci. 240, 37-48 (2004)

13. Labouriau, A., Cox, J.D., Schoonover, J.R., Patterson, B.M., Havrilla, G.J., Stephens, T., Taylor, D.: Mössbauer, NMR and ATR-FTIR spectroscopic investigation of degradation in RTV siloxane foams. Polym. Degrad. Stab. 92, 414-424 (2007)

14. Kim, S., Lee, C.-Y.: Jin, M.H-C.: Fourier-transform infrared spectroscopic studies of pristine polysilanes as precursor molecules for the solution deposition of amorphous silicon thin-films. Sol. Energy Mater. Sol. Cells 100, 61-64 (2012)

15. Ahangaran, F., Hassanzadeh, A., Nouri, S.: Surface modification of Fe3O4@SiO2 microsphere by silane coupling agent. Int. Nano Lett. 3, 23 (2013)

16. Launer, P.J.: Infrared analysis of organosilicon compounds: spectra-structure correlations. In: Anderson, R., Arkles, B., Larson, G.L. (eds.) Silicon Compounds: Register and Review, 4th edn, pp. 100-103. Petrarch Systems, Bristol, PA (1987)

17. Deka, B.K., Maji, T.K.: Effect of $\mathrm{SiO} 2$ and nanoclay on the properties of wood. Polym. Bull. 70, 403-417 (2012)

18. Camino, G., Lomakin, S.M., Lazzari, M.: Thermal polydimethylsiloxane degradation. Part 2. The degradation mechanisms. Polymer 43, $2011-2015$ (2002)

19. Camino, G., Lomakin, S.M., Lazzari, M.: Polydimethylsiloxane thermal degradation Part 1. Kinetic aspects. Polymer 42, 2395-2402 (2001).

20. Cendrowski, K., Chen, X., Zielinska, B., Kalenczuk, R.J., Rümmeli, M.H., Büchner, B., Klingeler, R., Borowiak-Pale, E.: Synthesis, characterization, and photocatalytic properties of core/ shell mesoporous silica nanospheres supporting nanocrystalline titania. J. Nanopart. Res. 13, 5899-5908 (2011) 
21. Schnyder, B., Lippert, T., Kötz, R., Wokaun, A., Graubner, V.M.: Nuyken, O: UV-irradiation induced modification of PDMS films investigated by XPS and spectroscopic ellipsometry. Surf. Sci. 532, 1067-1071 (2003)
22. ASTM C1463-00, Standard Practices for Dissolving Glass .Containing Radioactive and Mixed Waste for Chemical and Radiochemical Analysis, ASTM International, West Conshohocken, www.astm.org (2007) 